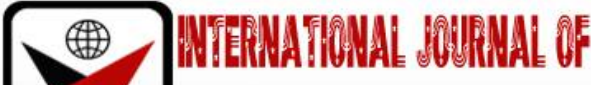

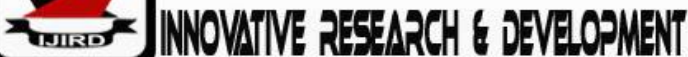

ISSN 2278 - 0211 (Online)

\section{Effects of Strategy Control Measures on Strategy Implementation at the Lake Victoria North Water Services Board, Homabay County, Kenya}

\author{
Thomas Okoth Otieno \\ Masters Student, Department of Business Economics, Tom Mboya University, Kenya \\ Dr. Victor Aliata \\ Lecturer, Department of Business and Economics, Tom Mboya University, Homabay, Kenya
}

\begin{abstract}
:
The Lake Victoria North Water Services Board (LVNWSB) in Homabay initiated a project with the aim of improving and expanding the network and infrastructure for drinking water and its sanitation in the county of Homabay. At that time, about $92 \%$ of the population had no access to piped water which was also of poor quality and high cost. Only $8 \%$ of the residents benefited from a continuous water supply. The Homabay Project is worth Ksh 300M which was to be completed by 2017 but up to date it has not been completed. The objective of this study was to establish the effect of strategy control measures on strategy implementation at the LVNWSB, in Homa Bay County, Kenya. The stakeholder theory was used in the study that suggests that an organization is a social construction made of interaction of various stakeholders. This study used correlation survey design. The target population for this study was 50 employees of LVNWSB. Census method was used to survey the target population. The respondents were given questionnaires that were administered through drop and pick method. The questionnaires were pre-tested by conducting a pilot survey from 5 respondents taken from the 50 employees using the internal consistency technique by employing Cronbach Coefficient Alpha test for reliability. Validity was determined using Content Validity Index (CVI). The research instrument was designed to collect qualitative and quantitative data. The researcher used multiple regression analysis using SPSS so as to determine the effects of independent variables on dependent variable. The study findings revealed that strategic control systems have a positive significant effect on strategy implementation $(\beta=.389, p=.000)$. The study concluded that strategic control systems have positive effect on strategy implementation. The study therefore recommends that the government improves the strategic control measures to enhance strategy implementation at LVNWSB. Findings from this study will be valuable to a number of stakeholders in and outside the water sector: expanding existing knowledge, referencing and finding comparisons in the quest of getting an ideal strategy-ethics composition and policy approach to stakeholder involvement that would improve service delivery.
\end{abstract}

Keywords: Strategy, strategy control measures, strategy implementation, Homabay County

\section{Introduction}

In Kenya, the number of water construction projects is increasing from time to time. However, it becomes difficult to complete projects in the allocated cost budget, taking into account the scarce financial resources, corruption and failure to involve stakeholders in such projects (Maina, 2013). Stakeholders' involvement is key to development projects. At times, minor decisions and emergency situations are not good for stakeholder participation, a very complicated situation with serious impacts warrant stakeholder involvement and when done proactively, rather than in response to a problem, help to avoid problems in the future,Feng, W., Crawley, E. F., Weck, O. d., Keller, R., \& Robinson, B. (2010). Public participation is usually to share information with, and gather input from members of the public who may have an interest in a project. The Constitution of Kenya 2010gives citizen the right to take part in activities that have a direct bearing on their lives (Mbaabu,2012).

The development and management of water resources on a major scale has traditionally been dominated by public or private monopolies. However, as economies mature there is growing evidence that institutional and economic reforms can allow market forces to play a part, particularly in-service sectors like water supply and sanitation. For example, there is a diversity of delivery options for water services across countries, which is characterised by a mixture of public utilities, private companies and other institutional forms such as cooperatives and not-for-profit entities. In many instances the incumbent service provider, whether private or public, enjoys either a monopoly or a dominant market position. However, in the absence of competition, many of these service providers become inefficient, provide unsatisfactory service, and are unable to keep up with growing consumer demand from existing and new customers (Walingo V. 2015). 
Encouraging innovation to flourish requires a regime that provides strong economic and financial incentives to suppliers and consumers of water. Water tariffs set at sustainable cost-recovery levels would promote more careful and efficient use, and reward the development and spread of water-efficient appliances and practices. The use of abstraction charges, bulk water tariffs, and pollution charges are also a necessary part of this wider incentive system, as they make water-efficient options more competitive. On the other hand, 'perverse' incentives such as subsidies - which encourage waste and over-use of water - should be removed, as there are much more effective and cost-efficient instruments than cheap or subsidised water to address the potential impacts of water prices on disadvantaged groups or industries (Walingo V. 2015).

Hussey (2010) sites that strategy implementation involves a five-step process namely, envision, activate, install, ensure, and recognize. Further, Hussey (2010), states that the implementation of strategy remains one of the most difficult areas of management. Its success depends both on the selection of an appropriate strategy and converting that strategy into action. If one of these aspects is deficient, the strategy may either fail or be less effective than it should be but it is often difficult to know after the event which aspect went wrong. According to Pearce and Robinson (2014), strategy implementation is the process through which strategy is translated into functional and operational targets. This is supported by Kotter and Best (1996) when they state that implementation addresses the who, where, when and how, and it is thus the tactic that drives the strategy of the company.

Pearce and Robinson (2014) make the argument that to be successful; the strategic plan must have the support of every member of the firm. The more often primary stakeholders hear about the strategy, its elements, and ways to measure its success, the greater the possibility that they will undertake it as part of their daily work lives. This positive reinforcement increases support of the plan and belief in its possibilities (Bechtell and Michele, 1995). Hussey (2010) further explores the subject of successful strategy implementation by introducing the concept of 'soft' and 'hard' aspects of implementation. He argues that there are soft and hard elements which need to fit together if the strategy is to be implemented. The soft elements comprise the behavioral dimensions while the hard elements comprise theanalytical dimensions to the process of making and the subsequent implementation of strategy. He contends that the issue then becomes one of creating a strategic fit between the soft and hard elements and organizational variables.

Human Resource can help effect improvements in both technology and business processes by helping to break down silos and enhance cross-company communication, top to bottom, side to side. Unless employees have real incentives to implement the strategy, they will not commit to it, and the strategy will probably fail.

Galpin (1998) takes the position that what really makes the difference between successful and unsuccessful strategy deployment is the way management motivates and educates its people to act on a business strategy. While motivation and education are important, they are hardly adequate. When groups of employees fully understand the contents and the logic behind a strategic objective, they tend to feel a stirring inside to do something to achieve it especially when they can see what's in it for them. Becker, et al. (2011) observes that while human capital is the foundation for creating value in the new economy, human assets are the least understood by most business leaders and therefore the least effectively managed.

\section{Literature Review}

Strategic control is one of the processes used in organization to control information and execution of strategic plans when implementing strategies. Defining the roles of Stakeholder involvement during strategy implementation is one of the strategic control measures to ensure the stakeholders understand what is expected of them. In a study conducted by (Wainganjo and Chepkoech,2015) conducted in Nairobi on the role of stakeholders in strategy implementation using correlation co-efficiency established that there is relationship between the roles of stakeholders and stakeholders involvement and they affect strategy implementation of organizations, however the study did not indicate specific roles of stakeholders while being involved in strategy implementation.

According to Macharia, (2011) in the study 'challenges of Strategy implementation in oil industry' conducted in Kenya. The study adopted across-sectional survey (census) design. The study found out that involvement is another strategy control measure in implementing strategy, as a success factor since organizations are networks of stakeholders and their involvement with affect positive or negatively the implementation of strategies, since involvement fosters partnership and solving collaboration problems. The researcher in this study concluded that organization should continue involving stakeholders in the implementation of strategies to enable organization achieve their objectives. Though the researchers concluded that involvement of stakeholders is one of the success factors in strategy implementation, the study did not indicate the levels of stakeholder involvement and which level is key to successful implementation of strategies hence this study tends to establish the levels of stakeholder involvement which influence positively strategy implementation. Stakeholder involvement practices need to be monitored when implementing strategy in organizations, this is necessary to ensure the practices are in line with given organization's policies. A study carried out by (A.J.Munene, 2013) conduced in Kisumu Kenya, using a case study established that universal stakeholder involvement practices helps in unifying the strategy implementation strategies though the study indicated that the practices help in unifying the strategy implementation, the study did not highlight the effect of the practices in specific but in general. This study sought to establish the specific practices of stakeholder involvement and the effects in strategy implementation. 


\section{Methodology}

This study used correlation research design. This design measured two variables with the aid of an intervening variable: independent variable and dependent variable. The independent variable was stakeholders' involvement which was measured by three sub-variables (activities of interest, strategic control measure and Division of labour) and the dependent variable is strategy implementation which was measured by innovation, new products and motivation. In light of this, the design was the best to fulfill the objective of the study since the results was expected to provide an insight in understanding how primary stakeholders relate to strategy implementation in LVNWSB Newsletter 2002.

The target population for this study was the50 employees of LVNWSB. Census method was used to survey the target population. The study also used the Focus Group Discussion to get the touch of the consumers.

Correlation analysis and a multiple regression analysis was calculated using SPSS so as to determine the relationships between the variables.

Independent variable and dependent variable

Model Independent variable and dependent variable

$\mathrm{Y}=\mathrm{a}+\beta 1 \mathrm{X}_{1}+\mathrm{e}$

Where,

$\mathrm{Y}=$ Strategy Implementation

$\mathrm{a}=$ the constant term

$\mathrm{X}_{1=}=$ Strategic Control Measures $\quad \beta 1=$ the slope for reviewing Strategic Control Measures

$\mathrm{e}=$ Error term

\section{Findings and Discussions}

\begin{tabular}{|c|c|c|c|}
\hline Statements on Strategic Control Measures & N & Mean & Std. Deviation \\
\hline $\begin{array}{c}\text { Mechanism of control measures in place in strategy } \\
\text { implementation }\end{array}$ & 44 & 2.20 & 1.025 \\
\hline $\begin{array}{c}\text { Risk identification methods on the strategic control measures } \\
\text { in place }\end{array}$ & 44 & 2.86 & 1.069 \\
\hline $\begin{array}{c}\text { Financial and regulatory measures in place to mitigate } \\
\text { strategy control measures issues }\end{array}$ & 44 & 2.93 & 1.319 \\
\hline $\begin{array}{c}\text { Specific role allocation to stakeholders } \\
\text { The level of influence of stakeholder's involvement in strategy } \\
\text { implementation }\end{array}$ & 44 & 3.23 & 1.236 \\
\hline
\end{tabular}

Table 1: Descriptive Statistics on Strategic Control Measures

The findings in Table 1 indicate that the mean range of respondents' rating on strategic control measures is between 2.20 and 3.23 with standard deviations ranging between 1.02 and 1.23 . Examining each of the response, the findings indicate a low extent of rating $(M=2.20, S D=1.02)$ of mechanisms of control measures in place in strategy implementation. It was also clear from the findings that there is a less extent of practice of risk identification methods on the strategic control measures in place $(\mathrm{M}=2.86, \mathrm{SD}=1.06)$ as well as financial and regulatory measures in place to mitigate strategy control measures issues $(M=2.93, S D=1.31)$. However, the findings indicated a moderate extent of specific role allocation to stakeholders $(3.23, \mathrm{SD}=1.236)$ as well as the level of influence of stakeholder's involvement in strategy implementation ( $\mathrm{M}=3.09, \mathrm{SD}=1.25)$. An overall rating of the extent of strategic control measures revealed a mean of 2.86, which is less extent.

In order to test the study hypothesis, which stated that 'Strategic control system has no effect on strategy implementation at the LVNWSB in Homa Bay County, Kenya', the findings were discussed in reference to Tables 2, 3, 4.

\begin{tabular}{|c|c|c|c|c|c|c|c|c|c|}
\hline \multirow[t]{2}{*}{ Model } & \multirow[t]{2}{*}{$\mathbf{R}$} & \multirow{2}{*}{$\begin{array}{c}\mathrm{R} \\
\text { Square }\end{array}$} & \multirow{2}{*}{$\begin{array}{l}\text { Adjusted } \\
\text { R Square }\end{array}$} & \multirow{2}{*}{$\begin{array}{l}\text { Std. Error } \\
\text { of the } \\
\text { Estimate }\end{array}$} & \multicolumn{5}{|c|}{ Change Statistics } \\
\hline & & & & & $\begin{array}{c}\text { R Square } \\
\text { Change }\end{array}$ & $\begin{array}{c}F \\
\text { Change }\end{array}$ & df1 & df2 & $\begin{array}{c}\text { Sig. F } \\
\text { Change }\end{array}$ \\
\hline 1 & $.866^{\mathrm{a}}$ & .750 & .731 & .22751 & .750 & 39.965 & 3 & 40 & .000 \\
\hline \multirow{2}{*}{\multicolumn{3}{|c|}{ Model }} & \multicolumn{3}{|c|}{$\begin{array}{l}\text { Unstandardized } \\
\text { Coefficients }\end{array}$} & \multicolumn{2}{|c|}{$\begin{array}{l}\text { Standardized } \\
\text { Coefficients }\end{array}$} & \multirow[t]{2}{*}{$\mathrm{t}$} & \multirow[t]{2}{*}{ Sig. } \\
\hline & & & & & d. Error & \multicolumn{2}{|c|}{ Beta } & & \\
\hline \multirow[t]{4}{*}{1} & \multicolumn{2}{|c|}{ (Constant) } & \multicolumn{2}{|c|}{.693} & .231 & & & 2.996 & .005 \\
\hline & \multicolumn{2}{|c|}{ Activity of interest } & \multicolumn{2}{|c|}{-.194} & -.091 & \multicolumn{2}{|c|}{-.223} & -2.138 & .039 \\
\hline & \multirow{2}{*}{\multicolumn{2}{|c|}{ Strategy control }} & \multirow{2}{*}{\multicolumn{2}{|c|}{.298}} & .065 & \multirow{2}{*}{\multicolumn{2}{|c|}{$\begin{array}{l}.389 \\
502\end{array}$}} & 4.622 & .000 \\
\hline & & & & & .070 & & & 4.945 & .000 \\
\hline
\end{tabular}

Table 2: Factors Associated with Stakeholder Involvement in Strategy Implementation

Predictors: (Constant), Division of Labour, Strategy Control, Activity Interest

Dependent Variable: Performance2 
The findings indicate that stakeholder involvement accounted for $86.6 \%$ variance in strategic implementation as shown in the results ( $\mathrm{R}$ square $=.866, \mathrm{~F}(3,40) \mathrm{p}=.000$ ). These findings are significant, implying that the model is accurately fit. The percentage change in strategy implementation unexplained by the model was therefore $13.4 \%$, which is small as compared to the variance explained by the model. An examination of the contribution of each of the model coefficients reveals more. All the model coefficients have a positive significant effect on strategy implementation. Division of labour had the strongest unique contribution on strategy implementation $(\beta=.502, p=.000)$ implying that it has a moderate effect on strategy implementation. Both strategy control $(\beta=.389, p=.000)$ and activity of interest $(\beta=.223, p=.039)$ had weak positive effects on strategy implementation.

The findings on the stakeholder involvement and strategy implementation were also presented as controlling for the government policy. First, respondents were asked to rate the extent to which the government policy on stakeholder involvement and strategy implementation. The findings were then summarized in means and standard deviations and reported in standard linear regression model as an intervening variable. The findings for the overall model are presented as shown in Table 3

\begin{tabular}{|c|c|c|c|c|c|c|c|c|c|c|}
\hline \multicolumn{11}{|c|}{ Model Summary } \\
\hline \multirow[t]{2}{*}{ Model } & \multirow[t]{2}{*}{$\mathbf{R}$} & \multirow[t]{2}{*}{ R Square } & \multirow{2}{*}{$\begin{array}{l}\text { Adjuste } \\
\text { d R } \\
\text { Square }\end{array}$} & \multirow{2}{*}{$\begin{array}{l}\text { Std. Error } \\
\text { of the } \\
\text { Estimate }\end{array}$} & \multicolumn{6}{|c|}{ Change Statistics } \\
\hline & & & & & \multicolumn{2}{|c|}{$\begin{array}{l}\text { R Square } \\
\text { Change }\end{array}$} & $\begin{array}{c}\text { F } \\
\text { Change }\end{array}$ & df1 & df2 & $\begin{array}{c}\text { Sig. F } \\
\text { Change }\end{array}$ \\
\hline 1 & $.109^{a}$ & .012 & -.012 & .44129 & \multicolumn{2}{|c|}{.012} & .500 & 1 & 42 & .483 \\
\hline 2 & $.668^{b}$ & .447 & .420 & .33425 & \multicolumn{2}{|c|}{.435} & 32.208 & 1 & 41 & .000 \\
\hline 3 & $.779 c$ & .607 & .578 & .28511 & \multicolumn{2}{|c|}{.161} & 16.350 & 1 & 40 & .000 \\
\hline 4 & $.869 \mathrm{~d}$ & .755 & .730 & .22812 & \multicolumn{2}{|c|}{.148} & 23.483 & 1 & 39 & .000 \\
\hline \multicolumn{11}{|c|}{ a. Predictors: (Constant), GOP } \\
\hline \multicolumn{11}{|c|}{ b. Predictors: (Constant), GOP, activity_interest } \\
\hline \multicolumn{11}{|c|}{ c. Predictors: (Constant), GOP, activity_interest, strategy_control } \\
\hline \multicolumn{11}{|c|}{ d. Predictors: (Constant), GOP, activity_interest, strategy_control, division_labour } \\
\hline \multirow{2}{*}{\multicolumn{3}{|c|}{ Model }} & \multicolumn{3}{|c|}{$\begin{array}{c}\text { Unstandardized } \\
\text { Coefficients }\end{array}$} & \multirow{2}{*}{\multicolumn{2}{|c|}{$\begin{array}{c}\text { Standardized } \\
\text { Coefficients }\end{array}$}} & \multirow{2}{*}{\multicolumn{2}{|c|}{$\mathbf{t}$}} & \multirow[t]{2}{*}{ Sig. } \\
\hline & & & B & \multicolumn{2}{|c|}{ Std. Error } & & & & & \\
\hline \multirow[t]{2}{*}{1} & \multicolumn{2}{|c|}{ (Constant) } & 3.427 & .51 & & & & \multicolumn{2}{|c|}{6.719} & .000 \\
\hline & \multicolumn{2}{|c|}{ GOP } & -.092 & .12 & & & -.109 & -.70 & & .483 \\
\hline 2 & & onstant) & 1.624 & .50 & & & & 3.2 & & .002 \\
\hline & & GOP & -.046 & .09 & & & -.055 & -.47 & & .639 \\
\hline & Activ & ity interest & -.577 & -.10 & & & -.662 & -5.6 & & .000 \\
\hline 3 & & onstant) & 1.200 & .43 & & & & 2.73 & & .009 \\
\hline & & GOP & -.086 & .08 & & & -.102 & -1.0 & & .313 \\
\hline & Activ & ity interest & .449 & .09 & & & .515 & 4.8 & & .000 \\
\hline & Strat & egy control & .328 & .08 & & & .428 & 4.0 & & .000 \\
\hline 4 & & onstant) & .932 & .35 & & & & 2.6 & & .012 \\
\hline & & GOP & -.060 & .06 & & & -.071 & -.88 & & .380 \\
\hline & Activ & ity interest & .190 & .09 & & & .218 & 2.08 & & .043 \\
\hline & Strat & egy control & .305 & .06 & & & .398 & 4.68 & & .000 \\
\hline & Divis & sion labour & .341 & .07 & & & .495 & 4.8 & & .000 \\
\hline & & & a. Depe & ent Variabl & $e: p e$ & & $\mathrm{ce} 2$ & & & \\
\hline
\end{tabular}

Table 3: Effect of Stakeholder Involvement on Strategy Implementation While Controlling for Government Policy

Table 3 findings indicate that after controlling for the effect of government policy, activity of interest had a positive unique effect of $(\beta=.662)$ which was significant as indicated by a significant value of 0.005 , strategy control had a positive effect of $(\beta=0.428)$ which was significant at 0.005 and division of labour had a positive effect of $(\beta=.495)$ which was also significant.

Respondents were also asked to indicate the extent to which organization priority intervened on the stakeholder involvement and strategic implementation. The findings on the final model obtained after controlling for the effect of organizational priority were also presented as shown in Table 4. 


\begin{tabular}{|c|c|c|c|c|c|c|c|c|c|}
\hline \multirow[t]{2}{*}{ Model } & \multirow[t]{2}{*}{$\mathbf{R}$} & \multirow{2}{*}{$\begin{array}{c}\text { R } \\
\text { Square }\end{array}$} & \multirow{2}{*}{$\begin{array}{l}\text { Adjusted } \\
\text { R Square }\end{array}$} & \multirow{2}{*}{$\begin{array}{l}\text { Std. Error } \\
\text { of the } \\
\text { Estimate }\end{array}$} & \multicolumn{5}{|c|}{ Change Statistics } \\
\hline & & & & & $\begin{array}{c}\text { R Square } \\
\text { Change }\end{array}$ & $\begin{array}{c}\mathbf{F} \\
\text { Change }\end{array}$ & df1 & df2 & $\begin{array}{c}\text { Sig. F } \\
\text { Change }\end{array}$ \\
\hline 1 & $.091^{\mathrm{a}}$ & .008 & -.015 & .44208 & .008 & .349 & 1 & 42 & .558 \\
\hline 2 & $.689^{b}$ & .474 & .449 & .32572 & .466 & 36.368 & 1 & 41 & .000 \\
\hline 3 & $.781^{c}$ & .610 & .581 & .28406 & .136 & 13.908 & 1 & 40 & .001 \\
\hline 4 & $.866^{\mathrm{d}}$ & .750 & .724 & .23039 & .140 & 21.805 & 1 & 39 & .000 \\
\hline
\end{tabular}

a. Predictors: (Constant), ORGP; b. Predictors: (Constant), ORGP, activity of interest; c. Predictors: (Constant), ORGP, activity of interest, strategy control; d. Predictors: (Constant), ORGP, activity of interest, strategy control, division of labour

\begin{tabular}{|c|c|c|c|c|c|c|}
\hline \multirow{2}{*}{\multicolumn{2}{|c|}{ Model }} & \multicolumn{2}{|c|}{$\begin{array}{l}\text { Unstandardized } \\
\text { Coefficients }\end{array}$} & \multirow{2}{*}{$\begin{array}{c}\begin{array}{c}\text { Standardized } \\
\text { Coefficients }\end{array} \\
\text { Beta }\end{array}$} & \multirow[t]{2}{*}{$\mathbf{T}$} & \multirow[t]{2}{*}{ Sig. } \\
\hline & & $\mathrm{B}$ & Std. Error & & & \\
\hline \multirow[t]{2}{*}{1} & (Constant) & 2.968 & .185 & & 16.053 & .000 \\
\hline & ORGP & .032 & .054 & .091 & .591 & .558 \\
\hline \multirow[t]{3}{*}{2} & (Constant) & 1.178 & .327 & & 3.606 & .001 \\
\hline & ORGP & .062 & .040 & .177 & 1.553 & .128 \\
\hline & Activity of interest & -.600 & -.099 & -.688 & -6.031 & .000 \\
\hline \multirow[t]{4}{*}{3} & (Constant) & .719 & .310 & & 2.320 & .026 \\
\hline & ORGP & .041 & .036 & .117 & 1.161 & .253 \\
\hline & Activity of interest & .478 & .093 & .548 & 5.157 & .000 \\
\hline & Strategy of control & .304 & .081 & .396 & 3.729 & .001 \\
\hline \multirow[t]{5}{*}{4} & (Constant) & .685 & .252 & & 2.724 & .010 \\
\hline & ORGP & .002 & .030 & .007 & .079 & .938 \\
\hline & Activity of interest & .196 & .096 & .225 & 2.036 & .049 \\
\hline & Strategy of control & .297 & .066 & .388 & 4.502 & .000 \\
\hline & Division of labour & .344 & .074 & .500 & 4.670 & .000 \\
\hline \multicolumn{7}{|c|}{ a. Dependent Variable: performance2 } \\
\hline
\end{tabular}

Table 4: Effect of Stakeholder involvement on Strategic Implementation Controlling for Organizational Policies

The findings in Table 5 indicates that after controlling for the effect of organization priority, activity of interest had a positive significant effect of $(\beta=0.688)$ on strategic implementation, strategic control had a positive significant effect of 0.396 , while division of labour had a positive effect of $(\beta=.500)$ which was significant as well. The findings on stakeholder involvement and strategic implementation are discussed in the subsequent sections objectively using both descriptive and inferential statistics.

The study sought to determine the effects of strategic control systems on stakeholder involvement in strategy implementation at LVNWSB in Homa Bay County, Kenya. The first step entailed establishing the extent of strategic control measure. In respect to this, the respondents were asked to rate the extent of strategic control measure on a five-point Likert scale. The key used was $1=$ No extent, 2 =Less extent, $3=$ Moderate great, $4=$ Great extent, $5=$ Very great extent. The findings were summarized using means and standard deviations and presented as shown in Table 1.

It is clear that strategic control measures contribute significantly to the overall variance in strategic implementation accounted by all the predictor variables. The model coefficient results indicated that strategic control measures have a positive significant effect on strategic implementation $(\beta=.389, p=.000)$. However, after controlling for the effect of government policies, strategic control measures maintained a positive significant but increased effect on strategic implementation $(\beta=.428, p=.000)$. Strategic control measures were also found to explain $16.1 \%$ variance in strategic implementation. This implies that the inclusion of the government policies makes the effect of strategic control measures on implementation of strategy more effective.

It was clear from the findings that there is a less extent of practice of risk identification methods on the strategic control measures in place $(\mathrm{M}=2.86, \mathrm{SD}=1.06)$ as well as financial and regulatory measures in place to mitigate strategy control measures issues $(M=2.93, S D=1.31)$.However, after controlling for the effect of government policies, strategic control measures maintained a positive significant but increased effect on strategic implementation $(\beta=.428, p=.000)$. This study concurs with Macharia, (2011) in the study 'challenges of Strategy implementation in oil industry' conducted in Kenya. The study found out that involvement is another strategy control measure in implementing strategy, as a success factor since organizations are networks of stakeholders and their involvement with affect positive or negatively the implementation of strategies, since involvement fosters partnership and solving collaboration problems.

\section{Summary, Conclusions and Recommendation of the Findings}

The study sought to determine the effects of strategic control systems on stakeholder involvement in strategy implementation at LVNWSB in Homa Bay County, Kenya. The null hypothesis stated that 'Strategic control system has no effect on in strategy implementation at the LVNWSB in Homa Bay County, Kenya.' There was lack of sufficient evidence to 
support the null hypothesis and as such, the study adopted the alternative hypothesis that strategic control systems have a positive effect on strategic implementation.

The study concluded that strategic control systems are practiced in the management. They are positively oriented and therefore have a positive effect on stakeholder involvement in strategic implementation. It can thus be deduced that strategic control systems are of paramount importance to the implementation of strategy. In addition, if the systems are improved, there is more likelihood of improvement of the strategic implementation due more involvement of stakeholders.

Clearly, strategic control systems do well with the specific role allocation to stakeholders and level of influence of stakeholder involvement in strategy implementation. However, the national government needs to critically examine mechanisms of control measures in place, risk identification and financial and regulatory measures so as to improve the overall effect of these measures on stakeholder's involvement in strategy implementation.

\section{Recommendation for Further Research}

For academic and organization discussions this study recommends that further research be conducted in the following areas: -

- To establish the influence of technology on performance of water projects in LVNWSB.

- To establish the effects of employee motivation on strategy implementation of organizations.

\section{References}

i. Bechtell, P. and Michele, L. (1995). the Management Compass: Steering the Corporation Using Hoshin Planning. New York: AMACOM.

ii. Becker, B. E., Huselid, M. A. and Ulrich, D. (2011). The HR Scorecard: Linking People, Strategy and Performance. Boston: Harvard Business School Press.

iii. Feng, W., Crawley, E. F., Weck, O. d., Keller, R., \& Robinson, B. (2010). Dependency structure matrix modelling for stakeholder value networks. Paper presented at the $12 \mathrm{TH}$ International dependency and structure modelling conference, Cambridge, UK.

iv. Galpin, M. (1998). Participatory Management Methods for Agricultural Research: Departments of Agricultural Extensions and Rural Development. University of Reading.

v. Hussey, D. (2010). Strategy and Planning: A Manager's Guide (New Ed.). New York: Wiley.

vi. Kotter, B. and Best, H. (1996). Management by Policy: How Companies Focus Their Total Quality Efforts to Achieve Competitive Advantage, Milwaukee: ASQC Quality Press.

vii. LVNWSB Draft Strategic Plan, 2013-17, Kisumu, LVNWSB

viii. LVNWSB Newsletter (2012). Kisumu, LVNWSB.

ix. Macharia, (2011). stakeholder involvement success factors in strategy implementation

x. Unpublished Master Thesis, UoN.

xi. Pearce, J. A and Robinson, R. B (2014). Strategic Management: Formulation, Implementation and Control, 10th Edition, Boston: Irwin McGraw Hill.

xii. Pfaffenberger, A. (2015). Optimal adult development: An inquiry into the dynamics of growth. Journal of Humanistic Psychology, 45(3), 279

xiii. Pride, W. M. and Ferell, O. C. (2013). Marketing Concepts and Strategies, Houghton Mifflin Company, Boston.

xiv. Wainganjo and Chepkoech, (2015) role of stakeholders in strategy implementation Unpublished Master Thesis, UoN.

xv. Walingo V. (2015). The influence of stakeholder involvement in strategy implementation. New York: State University of New York Press. 